\title{
Visions of visibility: LGBT communities in Turin
}

\author{
Charlotte Ross* \\ Department of Italian Studies, University of Birmingham, UK
}

(Received 15 June 2007; final version received 28 September 2007)

\begin{abstract}
Recent anti-discrimination campaigns by lesbian, gay, bisexual and transsexual (LGBT) activists in Italy have increased the visibility of these communities and individuals, but have not resulted in the desired improvements to legislation. In light of this situation, this article analyses modalities of 'visibility' as defined and desired by the active LGBT community in Turin, host city for National Pride 2006. The Pride committee scheduled an unprecedentedly 'visible' year-long programme of consciousness-raising and cultural events that went far beyond the more usual one-day march. Drawing on a series of interviews with members of the committee and of the lesbian community conducted in Turin in March and June 2006, the discussion explores social, cultural and political visibility in this LGBT community as it hosted National Pride.
\end{abstract}

Keywords: Pride; Italy; homosexuality; visibility

I think people live in a state of non-visibility, lacking self-acceptance; there are gay men and lesbians in Italy who are in hiding. (Andrea Benedino) ${ }^{1}$

\section{Introduction}

This article considers notions of visibility as defined and desired by lesbian, gay, bisexual and transgender (LGBT) communities in Turin, analysed in relation to activism surrounding the events of National Pride 2006, hosted by the city. Comments regarding visibility, such as that cited above, carry many implications, among them that LGBT individuals in Italy today suffer from a condition of closeted oppression, self-hatred, internalised homophobia, fear of public humiliation and even violence, among other potential difficulties. Lack of visibility may have multiple causes - self-censorship in the elaboration of identity, or the invisibilising of LGBT citizens through their lack of representation in political debate and marginalised sociocultural status, for example. As has been well documented in critical work on this area (Goffman 1963; Altman 1974; Weeks 1985; Faderman 1991), the effects of such conditions can be extremely negative.

However, this sketch is far from conveying a representative image of contemporary LGBT life in Italy. Indeed, as Benedino points out, since 2005 lesbian and gay relationships in particular have gained a heightened profile in Italy as the term 'PACS' has

*Email: c.e.ross@bham.ac.uk 
leapt into the public eye. This acronym for the proposed Patto Civile di Solidarietà (a form of civil union comparable to the Pacte Civil de Solidarité in France, which is open to heterosexual as well as same-sex couples ${ }^{2}$ ) has been discussed in such detail in parliament and the media that a new verb has been coined: 'pacsare' - to engage in a civil union (Smargiassi 2005). The level of public debate on the issue of civil partnerships has certainly resulted in a greater awareness of non-normative couples, families and individuals; public opinion has been generally felt to be supportive, as demonstrated by a 2006 Eurispes survey which revealed that $68.7 \%$ of Italian Catholics are in favour of PACS (Anon 2006a). Moreover, recently elected government officials include the openly gay Nichi Vendola, the openly transgender Vladimir Luxuria and the openly lesbian Titti De Simone (all three were Deputies for Rifondazione Comunista; Vendola has also been president of Puglia since 2005). This seems to suggest increased visibility and representation of LGBT communities within (certain) political parties.

There is a contradiction in these remarks regarding the alleged 'non-visibility' of LGBT individuals and the political attention to LGBT issues. The proposed PACS legislation and the election of openly gay, lesbian and transgender Deputies suggest that Italy is no longer the same country as that in which the Fascist Party decided that the 1930 Codice Rocco did not need specifically to criminalise homosexuality. Its vision of Italy was a country of upstanding citizens 'untainted' by homosexual desire and practices - a thoroughly homophobic position that both denied and pathologised homosexuality (Rossi Barilli 1999, 19-20). Alongside documented public support of the rights of same-sex couples to be publicly recognised and upheld in law, the Church has been vociferous in its condemnation of this possibility (Anon 2006b), and when the fifteenth legislature came to an end, the PACS legislation had yet to be approved, despite declarations by the Prodi Government that this issue constituted a priority among their policies during the 2006 elections. ${ }^{3}$ The substitute DICO law, indicating the Rights and Responsibilities of Stable, Co-habiting Couples (Diritti e doveri delle persone stabilmente conviventi), was approved on 8 February 2007, but has been criticised as inadequate in many respects, including the fact that couples must cohabit for nine years in order for inheritance rights to be recognised.

While acknowledging the symbolic significance of the PACS, this issue is not my main focus; I mention it now to give an idea of one of the major issues concerning LGBT rights recently under discussion at national level. My analysis focuses more precisely on visibility at a local level, specifically in Turin, seen in the context of national debates. I reflect upon the status of 'visibility' as a perceived positive condition, and interrogate what it meant to members of the LGBT communities in this city as they prepared for and hosted National Pride 2006.

\section{Rationale and methodology}

I chose Turin as the focus for my research principally because it had been selected as host city for the 2006 Pride Nazionale celebrations, but Turin also holds historic importance for the gay rights movement in Italy. Pride marches have grown in number and size across the world since the raiding of the Stonewall Inn in New York in 1969, which led to a small group marching in Philadelphia in the July of that year to campaign for the recognition of gay rights (Carter 2004). This proved to be the catalyst for the movements that were founded across North America and Europe in the years that followed. The United Italian 
Table 1. Attendance at Italian National Pride events.

\begin{tabular}{lclc}
\hline Year & Location & \multicolumn{1}{c}{ Event } & Estimated attendance* \\
\hline 1994 & Rome & First National Pride & 20,000 \\
2000 & Rome & World Pride & $500,000-700,000$ \\
2005 & Milan & National Pride & 100,000 \\
\hline
\end{tabular}

Note: *As a point of comparison, the first Pride event in London took place in 1972. In 2006 there were an estimated 600,000 people in attendance (see http://www.pridelondon.org).

Sources: http://www.arcigaymilano.org/crono/sezione.asp?IDEvento $=193 \&$ sez $=$ CIG+Milano\& sotto=Pride; Bonerandi (2005); http://www.arcigaymilano.org/dossier/movimento/stonewall/ stone.asp

Homosexual Revolutionary Front (Fronte unitario omosessuale rivoluzionario italiano, FUORI) was founded in Italy, more specifically in Turin, in 1971.

The history of gay Pride in Italy is one that for many years received little or no attention, but is finally being documented, both in printed form and on the web (Cristallo 1996; Rossi Barilli 1999; http://www.arcigay.it). ${ }^{4}$ The first public Italian demonstration took place in Sanremo in 1972, where members of FUORI and several other groups from across Europe expressed their objections to the activities of the Catholic-inspired Italian Sexology Centre that was holding an international conference there (Rossi Barilli 1999, 54-5). After several smallish gatherings in Bologna, Turin, Rome and Milan between 1978 and 1992, National Pride was established: a large-scale Pride event was designed to draw participants from across the peninsula and beyond, to reinforce numbers in attendance, and to create networks of support and activism. Estimated attendance figures demonstrate the continuing success of this initiative, and its international profile in the millennium year (Table 1).

Notably, in contrast to previous years, the organising committee in Turin decided to plan not only the traditional Pride march, but a year-long series of events and initiatives intended to raise the profile of LGBT individuals, their contributions to Italian culture and their place in history, as well as to celebrate Turin itself - the city that many consider to be the historic and spiritual home of gay rights activism in Italy. Such a sustained campaign for increased visibility demands critical attention and analysis. To undertake this, I conducted a series of group and individual interviews with active members of the LBGT population in Turin, including members of the Pride organising committee, during March and June 2006. Interviewees were selected in two ways. First, members of the committee were contacted individually. These included Enzo Cucco, the committee co-ordinator, and Andrea Benedino, a designated spokesperson for the committee. Second, I interviewed twelve individuals: eleven lesbian-identified women and one man. ${ }^{5}$ I selected members of the committee to interview according to their role and their contributions to LGBT life: aside from chairing the committee, Enzo Cucco is also President of the Sandro Penna Foundation based in Turin, and was closely involved with FUORI for many years; ${ }^{6}$ Andrea Benedino is national spokesperson for 'Gayleft', the LGBT committee within the Democrats of the Left (DS), now affiliated to the newly-formed Democratic Party. Other interviewees were self-selecting volunteers from the lesbian group L'Altramartedi (Alternative Tuesdays ${ }^{7}$ ), which meets at the Circolo Maurice, an Arci centre established in 1985 whose premises are the focus of LBGT life and activities in Turin. ${ }^{8}$ In recruiting 
these interviewees I chose to focus on lesbian engagements with the issue of visibility and the Pride events because in Italy, as elsewhere, lesbian populations have historically been less visible than gay men (Giartosio 2004, 156). Undeniably, bisexuals and transsexuals can also lay claim to suffer from marginalisation and invisibility (Firestein 1996; Namaste 2000). However, the scope of this research was not sufficient to include a focus on all the many facets of LGBT experience. The key issues I raised in these interviews were: first, whether or not, and where interviewees felt or wanted to be 'visible', either individually or collectively; second, their perceptions of Turin as an LGBT city; and third, their thoughts on the Pride parade and other Pride events, and the emphasis on being publicly seen.

In the analysis that follows, I draw on interview transcripts and other documentation to provide an overview of my findings in these three areas, relating notions of visibility to the achievement of sociopolitical status. I contextualise my discussion critically to elucidate the implications for individual and collective LGBT identity with reference to recent work in gender and queer theory, and in sexuality studies.

\section{Visibility: how, why and where?}

In the context of this discussion, the concept of visibility immediately evokes notions of 'coming out' of the metaphorical closet of repressed homosexual identity. FUORI as a group obviously played linguistically on the notion of 'coming out', which translates into Italian as 'venire fuori', describing the moment when an individual emerges from the dark recesses of a hidden identity, reified in the image of the enclosed space of the closet. Coming out into the light and demanding social recognition entails a process of selfaffirmation, self-identification and the assumption of a political stance. The closet space is figured as unhealthy, musty, cramped, for storing things rather than for living in. However, this metaphor has been problematised by Judith Butler, among others, who argues that the binary opposition in/out implies that the 'light of illumination' reveals a 'true' or 'essential' identity, which of course can never exist (Butler 1991, 16).

Diana Fuss further complicates the assumed process of becoming visibly 'out' by stating that:

To be out, in common gay parlance, is precisely to be no longer out; to be out is to be finally outside of exteriority and all the exclusions and deprivations such outsiderhood imposes. Or, put another way, to be out is really to be in - inside the realm of the visible, the speakable, the culturally intelligible. (Fuss 1991, p. 4)

To have 'come out', therefore, means to have brought one's sexuality 'out' of the margins and 'in'-to the realm of the speakable and figurable - 'inside' cultural discourse and representation. The potential consequences of this are multiple, including both a coming 'out' in which LGBT identity is visible but negatively coded by mainstream sociocultural discourses, and the modification of such normative discourses by the heightened profile of a marginal(ised) group.

Seidman's work on closeted identities and the mainstreaming of gay identities in the United States holds relevance here. Commenting on the increased visibility of gay men in the American media in recent years (but not of lesbians, who in his view remain 'conspicuously absent'), he argues that this hard-fought apparent improvement in status is not necessarily a productive result since gay men predominantly appear as 'straightlooking-and-acting or as buffoon-like jesters' (Seidman 2002, 1). Moreover, he points out 
that while cultural texts such as the films Philadelphia (1993) and In and Out (1997) seem to promote acceptance of homosexuality, it is a particular kind of gay identity that they embrace: 'normal gays' who do not threaten heterosexual dominance (Seidman 2002, 136-40). In the interviews I conducted, visibility and 'normality' seemed to be linked in a manner fitting with this kind of assimilationist agenda - one that seeks to improve the rights of minority groups without challenging or attempting to reform the status, views and practices of the heterosexual majority (Seidman 2002, 175). The difficulty of negotiating visibility as an LGBT individual, of being both 'out' and 'in', is one that the interviewees seemed to confront on a daily basis. As I argue, the majority of people I spoke to aspired both to be visible as members of the LGBT population and to be accepted as 'normal' - an objective that demands differing levels of compromise or selectivity in terms of self-presentation for each individual.

The interviews I conducted with lesbians revealed a general perception of a lack of LGBT visibility in Turin, particularly with regard to women. This was seen to be reflected in the absence of specifically lesbian spaces or designated evenings at LGBT bars and clubs. Paola (40) told me that the Circolo Maurice is 'the only association that has a visible lesbian group. There are other places that hold lesbian evenings, but this is the only association where the word "lesbian" appears.' Within the LGBT population, it was felt that 'women "hide" themselves better' (Franco, c.30), partly because they are less active in clubs and bars (Daria, 28) and tend to spend more time at dinner parties in private houses. Being socially and culturally 'invisible' as a group can have its advantages: Valeria (23) asserts that she has never been subjected to violence on account of her sexual identity 'perhaps because people don't realise that we are gay. They don't even think we might be lesbians.' However, several women I spoke to raised the issue of isolation: not only are lesbians invisible to non-LGBT individuals, but also to each other. Monica (35) recalls the experience of walking down the street asking herself if it is possible that she is the only lesbian around. ${ }^{9}$ Searching for a lesbian community in the women around her at university left her frustrated: 'Even walking up and down the corridors I thought I recognised quite a few, but I didn't know them and had never spoken to them so I couldn't be sure that they were lesbians.'

Several women asserted pride in their identity, together with a desire to be publicly visible and recognised as lesbian, but also revealed that they are selective about the contexts in which they seek this recognition. Claudia (42) is self-employed and therefore has no need to conceal her sexual orientation at work, but still takes care in public when being affectionate with her girlfriend so as not to arouse hostility. Paola identified as a lesbian relatively recently, but refuses to hide her sexual orientation; having never lived a 'closeted' life, she finds the idea of self-censorship a little ridiculous: 'I am 40 years old; how could anyone dare to tell me how to live my life?' However, she told me that she would be happier in a separatist context: 'If there were a lesbian separatist group in Turin, I'd go.' Therefore, her preferred environment in which to live her identity is still 'outside' mainstream society and discourse. Valeria had just come out in her university seminar on the day we spoke because she disagreed with the lecturer about the concept of heteronormativity. For her, this was an important affirmation of her political stance; however, this remains a university environment (i.e., non-mainstream) comprising her classmates, who are mostly female, including two other lesbians - again, she is 'out' but 'in'. 
Giulia (c.40) has only recently joined the active LGBT population, having spent many years in a non-scene relationship, ${ }^{10}$ and is rather hesitant about the benefits of being more visible: 'For better or worse I've been more active for a few years now.' Having felt isolated and unsure when first coming out, she has been through what she terms 'difficult periods' and therefore chooses to live her sexual orientation quietly: 'I didn't want to thrust it in everyone's face.' Similarly Daria, despite joking that she considers herself generally visible as a lesbian to the point of having a large ' $L$ ' tattooed on her forehead, avoids discussing her personal life or sexual orientation at work: 'I don't shout about it in the office; it is a question of not wanting any trouble. I need to be calm and I don't want to have to defend myself. ... I live every day in a world where I have to defend myself.' Thus the protective invisibility that Valeria describes comes at a price: that of censuring one's behaviour to avoid a negative reaction, or of temporarily effacing a part of one's identity.

The difficulty of negotiating (in)visibility as a lesbian in public (heterosexual) spaces had proved challenging for Daria, who identifies as a butch lesbian, and has restricted her choice of social space:

I started to go to gay bars so as not to have any trouble. If I go to a gay bar with a girl I like, I can kiss her. In a straight bar I can do this, because I look masculine so people think I am male; but then they look at you disapprovingly, they ask you politely if you can leave...just for a kiss! One manager said to me: 'Look, this is not a gay bar.'

Here Daria is faced with several possibilities: of being visible as a lesbian in the dominant heterosexual context and judged negatively, or even excluded, according to heteronormative logic; of being 'mistaken' for a young man in this context, and therefore accepted, at the cost of the erasure of her lesbian identity and the anxiety produced by concern as to whether this mistaken recognition will hold out; ${ }^{11}$ or of spending time in LGBT or private spaces where she is more fully able to embody her identity. Her experiences of being both 'in' and 'out' (i.e., visible as a lesbian while simultaneously rejected by the dominant heterosexual context, or accepted as a lesbian in a marginal space) tally with Fuss's theoretical reflections cited above.

Given the complexity of these situations, it becomes increasingly necessary to define what is at stake in the process of becoming visible. Claudia's parents, now in their sixties, equate all modalities of homosexuality with exhibitionism: in their view, to live a homosexual life means to flaunt one's sexuality in public. The lesbians I spoke to were certainly not seeking to indulge in exhibitionism (as will be explored in more depth in due course) in relation to the Pride parade; on the contrary, even though they are all 'out' in social and often familial contexts, many of them have chosen not to declare their sexual orientation at work and self-police their behaviour in public.

Two main modalities of visibility emerged in these interviews: being visible to other LGBT individuals, and being visible to non-LGBT individuals. Groups such as L'Altramartedi are vital because they allow isolated lesbians to find each other in the first instance, and to discuss their shared issues and interests:

It is only by going to these [LGBT] places and meeting people that you can say, hey, I've seen you around somewhere. Often you see lots of lesbians around but it is only in these situations that it is possible [to talk to them]; in a way it allows us to identify each other. (Monica)

Such meetings foster a sense of community - one that depends not solely on geographic or class affiliations, for example, but predominantly on 'a sense of camaraderie with other lesbians, a sense of support, shared understanding, shared vision, shared sense of self, 
"as a lesbian" vis-à-vis the outside world'. ${ }^{12}$ As Rothenberg $(1995,171-2)$ points out, the notion of an LGBT 'community' is open to multiple interpretations and should be used with caution. What seems clear however, is that L'Altramartedì and other comparable groups may enable hitherto unknown but 'imagined communities' to establish themselves in more material ways. ${ }^{13}$

Where social models and a sense of community are lacking, individuals who do not correspond to dominant models of identity risk being unrecognisable, to themselves as well as to others, which may increase their isolation: 'A person who feels alone and who doesn't recognize her or himself in any group is frightened of coming forward' (Giulia). Butler $(2004,31)$ has discussed this issue in relation to Hegelian thought and takes the discussion a step further: '[I]f there are no norms of recognition by which we are recognizable... we are not possible beings.' By this logic, those who are not socially recognised according to cultural norms, effectively do not exist. Mainstream social discourses can be vital in aiding or impeding social recognition. Claudia commented that when she first began to come out twenty years ago, it was incredibly difficult since her friends and colleagues lacked any awareness of, or vocabulary to discuss, gay and lesbian life. Now, in contrast, LGBT issues have entered the mainstream, facilitating debate: 'PACS is discussed on TV, people realise that gay people exist.' Similarly Franco, who is not out at work, says he has nevertheless spoken about homosexuality often with colleagues in recent months because some key topics were already in the public domain. Discursive contexts can and do change, enabling marginalised groups to attain the kind of recognition that Butler theorises.

Being recognisably out and visible is about making a choice to identify oneself as LGBT, and signalling this to others in some way, such as through spoken language or visual signs. This is far from a one-off process, however, since being out means having to declare one's sexual orientation in every new context, effectively having 'to come out continually' (Maher and Pusch 1995, 27). Aesthetics may play a part in this. Daria identified two categories of lesbian aesthetic that she defined as the 'unimaginables' ('insospettibili') whom one would never suspect of being anything other than 'normal' (i.e. heterosexual), and the '100-yarders' ('centrometriste'): lesbians who are recognisable as such even at a distance. This latter aesthetic has advantages and disadvantages: an individual may lose the protection of invisibility, but may also avoid having to announce continually her sexuality verbally in each new situation. Monica was especially keen to avoid having to do this in a professional context, and even suggested that it was preferable to come out unprompted in a job interview to avoid being placed in potentially difficult situations later on.

Aesthetic visibility, and therefore social visibility, were perceived as much greater among gay men, with positive sociopolitical consequences:

It feels like I see lots more gay men around. It is true that it is easier to recognise the boys than the girls, so perhaps I just think I see more of them, but not only do I see them more, they seem to get things done more easily. ... They are much, much more active than us, they work at going out and being out. (Giulia)

Cumulative political, social and economic weight results from being numerous, active consumers who lobby for change. As Giulia says, the gay male population seems to have gained from its visibility and presence in the public sphere. If this is the case, then apart from social- and self-recognition, being 'out' in this way has potential political benefits. However, this kind of visibility demands that gay men situate themselves collectively to 
some extent different from and 'other' than the heterosexual population; as potentially disruptive to the dominant social order. Most of the people I interviewed did not want to be seen as disruptive, but to be accepted into society as 'normal', just like everyone else:

I think I am a normal person, I have a normal job, and what I do in bed is my business. (Giulia)

I used to feel abnormal. . . Right now I feel really well, I am just about to go and spend an evening with lesbian friends, in totally normal bars, a totally normal evening out with the girls. (Monica)

I am proud of being as I am. Of having a job, of going to work, of bringing home my wages each month, of having a house, a car, friends, that is, a totally normal life like my father, my mother, my sister, the people I know. (Daria)

Thus the negotiation of being visible is inevitably fraught with conflicting impulses. For an individual, being accepted by society as 'normal' may relieve stress and feelings of marginalisation, but it is unlikely to achieve improvements in social and legal status for the LGBT population at large. Moreover, rather than broadening dominant social attitudes, being recognised as 'normal', where 'normal' is understood in aesthetic terms or assumed lifestyle to mean heterosexual, may result in further problematic invisibilisation of LBGT individuals. Monica and Valeria want to lead a 'normal' social life and frequent mixed establishments, since in their view LGBT bars and clubs can lead to a form of ghettoisation. However, as Daria and others told me, this can mean necessarily acting and looking 'normal', which some individuals find restricting and uncomfortable.

While it is highly positive that interviewees regard themselves as emphatically not 'abnormal', their language recalls the problematic binary logic that characterises 'shame as normal's "other"” (Halberstam 2005, 221). If we are limited to binary thinking of this kind, it leaves little room for manoeuvre between what is construed as the shameful exhibitionism of an 'abnormal' sexual orientation and a form of normalising self-silencing achieved through 'cleaving to the ordinary and the quiet' (Halberstam 2005, 228). A queer perspective on the situation that disrupts the either/or formulation of shameful/normal opens up further possibilities of self-conception and realisation, enabling individuals to retain their sense of pride in their identities and to feel accepted without being constricted by the creeping normativity and self-policing that may attend the performance of a 'normal identity'. A queer reclaiming and resignification of the term 'normal' strives towards a sociocultural context in which diversity becomes the 'norm' rather than the pathologised 'other'; ${ }^{14}$ thus the sociocultural environment becomes a crucial factor in enabling LGBT visibility.

\section{Turin as an LGBT city}

As has been noted by many cultural theorists, historians and sociologists, the city may act as a draw for those who feel misunderstood, marginalised, scrutinised or persecuted in rural areas. Given the relative absence of social surveillance and concentration of LGBT individuals in urban centres in Italy (Barbagli and Colombo 2001, 88-9, 102), cities may provide LGBT people with a safe haven, a chance to start again and to create a new kind of queer family network. Franco, who came to Turin from a small village in Sicily to study at university and then stayed, concurs with this view: 'The city is definitely a place where a gay person can live better.' For Paola, the influx to the city of lesbians of diverse provenance leads to a positive, dynamic and mixed community. However, Turin is an 
ambiguous example of a city: both large enough to provide some anonymity, and small enough that one may be recognised, as became clear in the interviews I conducted.

Stereotypical depictions of Turin conjure a 'grey, dark, unwelcoming, northern' city whose inhabitants are typically 'understated, where you shouldn't stand out' (Cucco). Yet despite complaints about a lack of visibility, the LGBT reality of the city is viewed quite positively. Turin was described to me as generally gay-friendly, non-violent, secular and left-wing; indeed, the presidents of both the Province of Turin (Antonio Saitta, Margherita) and the Region of Piedmont (Mercedes Bresso, DS) are on the left. Enzo Cucco explained that Turin is a very experimental place, especially for the LGBT community: 'Turin has been a laboratory for many years for the gay rights movement. Not only was it born here, but a great deal of things that produced the gay rights movement were tried out here for the first time.'

The most visible legacy of this past is the annual Festival of Gay and Lesbian Cinema, 'From Sodom to Hollywood', now in its twenty-second year. ${ }^{15}$ Events such as these, and the bars and services that do exist, are a vital point of reference for LGBT individuals from all over Piedmont, as Andrea Benedino explained. Based in Ivrea, and collaborator on the programme of LGBT events 'Ivrea la gaya', ${ }^{16}$ Benedino is well aware of the issues faced by isolated LGBT individuals and the importance of LGBT spaces in the city:

I know many gays and lesbians who don't even live in Ivrea but in tiny villages of only a few hundred people and their only moments of freedom are when they take the car and go to Turin or Milan to gay bars. It is the only time during the week when they feel they can really be themselves. Otherwise they live their lives in small villages, where they are the victims of prejudice, discrimination and gossip.

The relative anonymity of the city and the establishments it provides enable these rurally based LGBT individuals to be visible as themselves, to be recognised and recognisable, albeit temporarily.

However, despite the city's activist past and importance as an LGBT urban centre, there has been no Pride parade in Turin since 1981. In Cucco's opinion there has been no significant increase of LGBT bars, clubs and establishments in the past 35 years. He explained that in the late 1960s many establishments such as the male saunas already existed, although not openly advertised as today. The changes he notes in recent years are the increase of mixed or 'gay friendly' establishments. Yet as Giulia explained, 'until it is "normal" for two women to kiss in public' this does not guarantee that same-sex couples will be exempt from intrusive stares and feelings of discomfort even in these contexts. Turin was selected as the host city for National Pride 2006 not because it was known as a rather homophobic environment in need of political activism, as had been the case when Bari was selected in 2003, but because it was a gay-friendly city with a particular history that needed 'to be shaken up a bit' (Cucco). Similarly, Claudia noted that while Turin is not 'a village where people stare at you unpleasantly', it is less international than Milan, and with a far less visible LGBT population.

Glancing across the peninsula at other cities, recent research names Bologna as the 'San Francisco d'Italia', with over double the LGBT population of Turin and Rome, for example, and a well-known tradition of tolerance; Milan has been defined the 'capitale gay d'Italia' due to its concentration of LGBT bars and clubs; Rome became a symbolic place of LGBT 'pilgrimage' for World Pride in 2000 (Barbagli and Colombo 2001, 193-6). Notably, LGBT life in Italy can be contrasted with experiences in North America, 
in particular, where gay villages have grown up around residential LGBT populations and the specific social and cultural services they require and provide. Where there are equivalents to these concentrations of LGBT life in Italy, they remain on a much smaller scale (e.g., Via Sammartini, Milan, known as 'Gay Street'). There is no significant clustering of LGBT venues or services in Turin, which in itself might be seen as a factor preventing the LGBT population from attaining greater visibility. Yet the geographic spread of establishments marked as either 'gay' or 'gay-friendly' on the LGBT map produced for visitors to Turin during Pride year, can also be interpreted more productively as a broadly established multifaceted tissue of sociocultural roots, embedded across the city as a whole, in a variety of more and less central districts.

If Turin is not a city in which one seeks to stand out, 'every time the city does stand out it is an event' (Cucco). Having successfully hosted the 2006 Winter Olympics, Turin was already enjoying increased visibility on a national and international level - a situation the Pride committee and the individuals I spoke to hoped would lead to many changes in the character and status of the city as an LGBT environment. Rather than to campaign for more numerous LGBT establishments, the immediate aim seemed to be that of rendering visible and valorising what already existed, and to allow LGBT individuals to claim their place openly in the city.

\section{Pride, parades and publicity}

As coordinator of the committee, Cucco was quick to emphasise a series of 'firsts' for Pride 2006: the first time that National Pride had involved such a long and expansive programme of events; the first time that it had taken place with the support of the local, regional and provincial authorities; the first time that it had been sponsored by these authorities (c. $€ 400,000$ ). Cucco's intention was always to establish dialogue between communities and the authorities: 'We deliberately opted for a low profile approach, we never responded to polemics with other polemics... because our objective is Pride, not polemics.' He described the programme of events as an opportunity 'to allow all the diverse components of the LGBT communities to be visible as they wish to be', as well as a moment to look forward and reflect on 'the future of the movement'. One key aspect of his approach, shared by the majority of people I spoke to, was that of inclusivity: 'We always said we didn't want to organize a self-referential Pride - that is, we didn't want Pride to be just for gays, lesbians and transsexuals, but we wanted to organize it so that it would be an event for everyone else as well.' In this, the committee can be seen to reflect developments in Pride events elsewhere that seek to include broader facets of the population as a whole for example, the tendency to reduce the label 'Gay Pride' to simply 'Pride', or to use more open terminology, as in the case of the 'Mardi Gras' carnival in Sydney. These events celebrate a diversity in which everyone can participate. ${ }^{17}$

For Giulia, inclusivity is vital because LGBT individuals and identities are 'transversal': they cut across perceived social barriers such as class or sex and are present in all sectors of society. Here she echoes Queer Nation politics that seek to undermine heterosexist assumptions about society and to assert the ubiquitous presence of queer individuals through slogans such as 'We are everywhere' (Davis 1995, 293). Recent debates in queer theory explore this transversality from another angle, analysing the ways in which class, ethnicity and sexuality, for example, intersect in complex and irreducible ways within 
the individual subject (Valocchi 2005, 762-4). In its anti-identitarian stance, queer theory explicitly rejects rigid or monolithic conceptions of the self, opening up the way for nonnormative and multiple modalities of being to flourish. These complexities and intersections were highlighted and fostered by the Pride committee through the events organised, contacts established and audiences in attendance, which Cucco described as specifically 'transversal'. In this vein, he was especially proud that the committee's hopes had been realised for the conference 'Fascism and Homosexuality: The Persecution of Homosexuals in Italy' ('Fascismo e omosessualità: la persecuzioni degli omosessuali in Italia ${ }^{18}$ ): first, the audience comprised both LGBT and heterosexual individuals; and second, LGBT victims were accorded their place in history alongside others who died in the Holocaust.

Similarly, Benedino emphasised the importance of publicly recognising LGBT contributions to cultural events. As spokesperson for Gayleft, his role is to ensure that LGBT issues remain at the forefront of political debate. He saw Pride 2006 as a chance for LGBT communities to be insistently present, active participants in annual Turinese events such as the September Music Festival (Settembre musica) and the Book Fair (Fiera del libro), and made sure that the pink Pride banners were visible in a range of cultural situations. ${ }^{19}$

The benefits of this LGBT presence in the cultural arena were already felt by many people to whom I spoke: Paola was involved in the events for International Women's Day and spoke of how the organisational work behind the National Study conference on Lesbian Identity and the performance 'Sistren/Sorelle' (8 March) enabled the lesbian and feminist community to create links with other organisations in the city. In particular, their collaboration with the Centro Interculturale Alma Mater enabled them to establish a dialogue with communities of immigrant women, opening up vital channels of communication for women who identify as lesbian and whose needs may not be served by existing support networks. ${ }^{20}$ These activities work to break down sociocultural barriers and to queer binary or monolithic conceptions of social subjects or groups, 'in ways that honour the complexity of human agency' (Valocchi 2005, 770).

As regards the parade itself, Pride demonstrations are often presented as occasions when LGBT individuals can 'really be themselves', can come out of the closets in which they exist on a day-to-day basis, at work, with their families - whether this be parents, children or husbands and wives - with friends, neighbours and acquaintances. For one glorious day they can throw off the pretence or constrictions of everyday routine, forced dissemblance, silencing and self-censorship, and revel in their rainbow glory, feather boas, sequins and larger-than-life personas. However, Cucco deliberately wished to expand this understanding of LGBT by seeking to promote a 'self-aware visibility': a political appreciation of the significance of being visible for all those involved in the parade, whether activists or night clubbers, and of being visible in the long term, not just in the moment. He insisted that 'we mustn't present the march as the chance to come and parade for a day, but it must be a chance to show that it is possible to live one's life all year, not just 17th June [the date of the parade]'. For Cucco, visibility entails 'full acceptance of self' in a sustained and comprehensive manner:" "True" visibility isn't just wearing feathers on your head, but it is wearing them, and being aware that I have feathers on my head all year.'

Feathers and sequins arose in other discussions, as interviewees sought to distance themselves from forms of behaviour and self-presentation seen as 'excessive', appropriate 
for the playful performances of the drag queens, but not for 'normal' LGBT people (Daria). The media was blamed for creating and perpetuating 'frou frou carnivalesque stereotypes' (Linda 28) that failed to represent the majority of the LGBT population. Notions of 'normality' were central to discussions of the parade, envisaged as 'not exclusively homosexual, but where the GLBT world comes together with heterosexuality'. ${ }^{21}$ A sense of unity and shared experience, it was hoped, would prove 'a way of getting ourselves accepted, of making people who consider themselves to be "normal" understand that we are normal too' (Sandra c.40). For Giulia, 'it is vital that many heterosexuals participate because their presence means being in a situation of normality. For me, the objective is not revolution but to appropriate normality.'

There is a fine line between assimilationist arguments and queer notions of 'normality' in these statements. Sandra wants to assimilate into the accepted realm of the existing order, while Giulia, despite her desire to avoid revolutionary tactics, is potentially more radical, wanting to queer and enlarge notions of 'the norm'. However, while many of those I spoke to complained of a lack of visibility, they were also reluctant to stand up and take the stage unless surrounded by a substantial crowd of 'legitimate' citizens; undertones of this perspective are present in Giulia's vision of a Pride strengthened by the presence of 'normal' heterosexual people, and made explicit in Daria's comment: 'It will be a bit like Pride in Rome 2000 that was not only for homosexual people but also for families ... so we could be visible without being alone.' While the collective nature of such an occasion is potentially productive for social integration and acceptance, and may facilitate the kind of vital recognition that Butler theorises, several interviewees shied away from this possibility; they admitted that the presence of 'normal' citizens would mean optional camouflage, in that if confronted by their employer, for example, their presence would not be tantamount to an admission of sexual orientation.

As mentioned above, we might identify in these remarks an unwillingness to assume openly an LGBT identity in a context inflected by the binary logic of shameful/normal, where perceived difference is construed as 'shameful'. Roberta Padovano, a member of the committee, defended everyone's right to participate in the parade as they thought best, whether this involved perceived 'excess' or not. For her, as for Cucco, protecting diversity of self-expression is a vital element of LGBT activism and life. Their commitment to this principle, and the committee's political engagement in general, ensured that this was far from being a homonormative, consumeristic Pride, as critiqued by Gay Shame collectives. $^{22}$

However the desire to be seen and accepted as 'normal' and the remarks regarding queer 'excess' as expressed by several of those I interviewed chime with Halberstam's observations on the view that the shame that many still associate with homosexuality can apparently be healed or redeemed by certain embodiments of normative identity: 'Contemporary gay pride politics suggests that gay white men can work through gay shame by producing normative masculinities and presenting themselves as uncastrated, muscular, whole' (Halberstam 2005, 228). While the desire to be accepted by society is wholly understandable, positioning oneself as a 'normal gay' as distinct from implicitly 'abnormal' LGBT individuals is problematic as it risks re-imposing many of the (hetero)normative standards of aesthetic/self presentation that LGBT and particularly queer populations have sought to destabilise and reject, on account of their being rigid, undesirable, unattainable and embedded both in normative logics and in hyper-consumeristic notions of 'wholeness' and beauty. The binary distinction of 
shame/normality identified by Halberstam is echoed in the opposition different/normal that inflects several of the interviewee responses cited above. These tensions are certainly not new; the desire to resignify difference as positive and the contrasting wish to assert equality with others can be compared to the goals of radical (revolutionary) versus equal rights (reformist) feminism - for example, as contrasting activist trends seeking either to disrupt and reinscribe sociocultural values and identities, or to extend parity within the existing system to a greater number of individuals.

In Italy, several Pride marches have already provoked comment within LGBT circles for their privileging of a normalising stance. At a conference in 2005, Luki Massa of Fuoricampo, a separatist lesbian group based in Bologna, discussed how the word 'normal' used to be rejected on the grounds of its inherent judgemental moralism, but remarked that the word had been seized upon for slogans at Pride marches in Italy: in Naples in 1996 protestors shouted 'Are we different? No, we're normal. ${ }^{, 2}$ She further observed that rather than fighting to be accepted and valued for diversity and transgression of oppressive norms and legislation, the LGBT population seems to be clamouring to emulate heterosexual individuals, notably through the PACS campaign, which in her view risks valorising marriage and monogamy over queer relationship practices. Here she echoes arguments put forward by Judith Butler, among others, who suggests 'it would constitute a drastic curtailment of progressive sexual politics to allow marriage and family, or even kinship, to mark the exclusive perameters within which sexual life is thought' (Butler 2005, 130). ${ }^{24}$

In this tension between radical and assimilationist politics, debates in Italy echo those found elsewhere. Benjamin Shepard (2001) has analysed the 'queer/gay assimilationist split' in America, which he traces from the opposition between the 'apologist' homophile movement and the gay liberationists of the late 1960s to contemporary rifts in the American LGBT activist world. Describing the Millennium March held in Washington on 30 April 2000, he notes how 'queers, who envisioned their movement as a critique of social, sexual and economic "regimes of the normal" rejected the Millennium March, while mainstream gay groups who sought to portray the gay community as "just like everyone else" turned to corporate sponsorship for the event'. While the differing views offered in Turin are broadly comparable to the differences of opinion depicted by Shepard, the absence of corporate sponsorship and the obvious political engagement in Turin do set it apart from the vision of the Millennium March Shepard presents. Yet the tension between conceptions of difference/normality remains.

In terms of legitimising the LGBT population, Turin 2006 arguably went further than any other National Pride, even including a welcome leaflet, in English and Italian, featuring a joint declaration of welcome by Antonio Saitta, Mercedes Bresso and Sergio Chiamparino, the Mayor of Turin ${ }^{25}$ (see Figure 1). While the national media was criticised for its stereotypical portrayal of LGBT lives, Turin's La Stampa was praised for its coverage of the entire Pride programme and for its weekly inclusion of an article on 'Torino gaya'. Radio Flash and Radio Onda gay also covered the events and their contributions were appreciated for raising the profile of LGBT groups and their activities. As mentioned before, it was felt that the general sociocultural and political context of Turin and Piedmont was favourable to promoting LGBT issues and rights, as is evidenced by didactic material used in local schools. The educational DVD and accompanying book, Nessuno uguale (No two alike; Agedo 2005), are designed to combat prejudice and facilitate discussion of LGBT issues in the classroom. Associated Turinese projects have included 


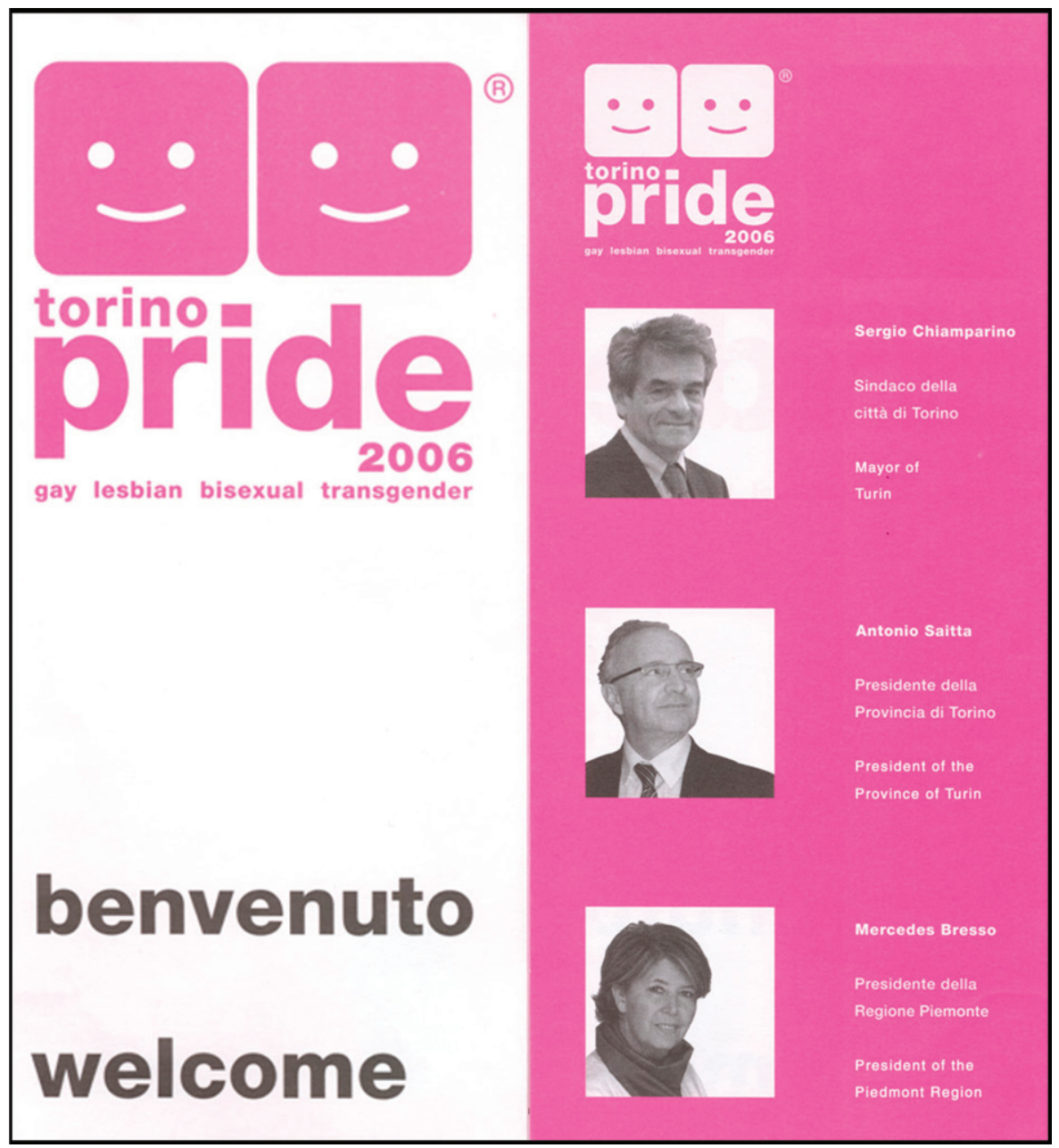

Figure 1. Welcome leaflet distributed to the public, compiled by the Turin Pride 2006 Committee, with the endorsement of the city, provincial and regional administration.

the 2003 competition for schoolchildren to design a poster that sought to combat discrimination. In contrast to the desire for acceptance as 'normal' expressed by interviewees, these campaigns focus on difference, and on the futility of being frightened by difference, made explicit in the winning design (Figure 2).

Homophobia is portrayed as an ungrounded fear of the pink sheep, or ungrounded fear of the apparent 'other'. Yet this runs counter to the desire expressed by interviewees to be seen precisely as 'uguale' ('alike'). Giulia discussed the demand for equal rights expressed in the Pride slogan, a rewording of Primo Levi's well-known text: 'If not now, then when? Equal rights for all' (Se non ora quando? uguali diritti per tutti). She gave a combative exhortation to all LGBT individuals to parade with enthusiasm: 'If we don't come out now when the hell are we going to do it?' The events of National pride are thus a catalyst to 'shake up' the city and its residents into actively seeking visibility and equal 


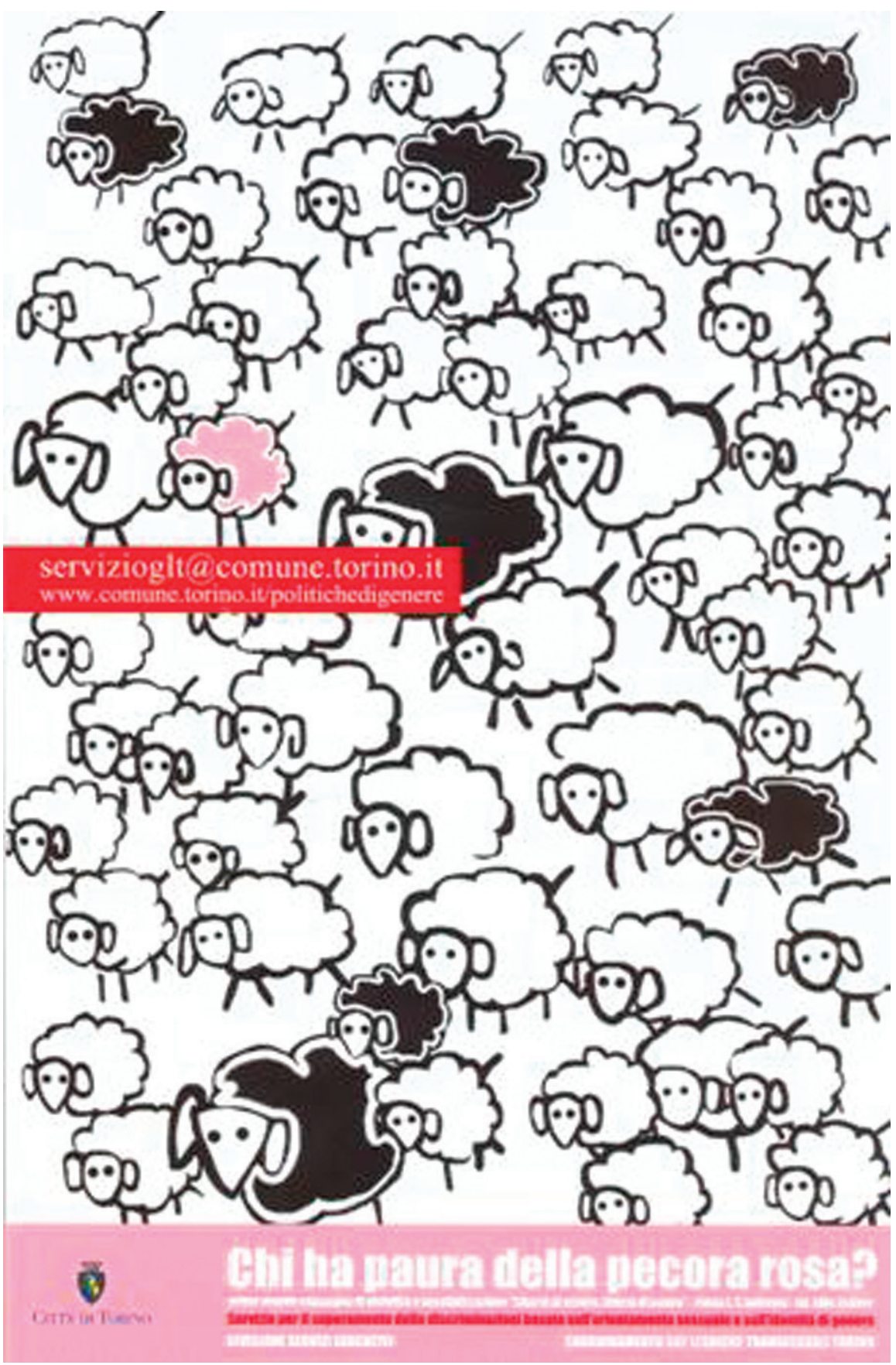

Figure 2. Winning design of the school poster design competition held in conjunction with the 2003 'Freedom to be, freedom to love' ('Libertà di essere, libertà di amare') campaign, organised by the Turin Gay, Lesbian and Transsexual Committee, in collaboration with Turin's Divisione Servizi Educativi, Servizio per il superamento delle discriminazioni basate sull'orientamento sessuale e sull'identità di genere. (The shaded sheep just above the email and web addresses is pink.). 
rights for LGBT people. Yet this slogan can itself be interpreted as a step away from a radical political agenda towards an assimilationist position.

One way to read this desire to be 'alike' is as resulting from a frustration with the kind of prejudice faced by LGBT individuals on an everyday basis. Few people spoke explicitly of prejudice, but it lurked on the fringes of many responses, such as Daria's comment: 'I live everyday in a world where I have to defend myself.' Despite her enthusiasm, Giulia also expressed doubts about being publicly out: she works with children and finds that in her professional context it is difficult to discuss LGBT issues either with the children themselves or their parents. Everyone to whom I spoke expressed a desire for increased visibility, for improved rights against discrimination and the right to register a publicly recognised partnership, yet the modality of this visibility remained uncertain due to the complexities resulting from unpredictable or openly homophobic responses by the general public.

\section{Conclusion}

Despite the tendencies towards an assimilationist stance, it was felt by most that National Pride, and in particular the parade, had the potential to impact quite radically on both the broader context, altering the social status and profile of the LGBT community in Turin, and on the individual's sense of self:

I don't deny that it will be an important moment for Turin; it will represent a breakthrough for Turin's GLBT community, because visibility is a problem in this community and this is the moment of greatest visibility. The parade will certainly shake up old orders, perhaps even create new ones; I feel this in myself too. (Franco)

The parade itself was widely considered a great success by those involved, with reports claiming attendance figures of between 50,000-100,000 people, and minimal disturbances (Santucci 2006; Minucci 2006). As hoped by the committee and the interviewees, it was indeed attended by a significant number of heterosexuals, including family groups, as well as by LGBT individuals and queer families. The floats demonstrated the diversity of the LGBT population; groups represented included dedicated night clubbers in elaborate outfits, religious groups such as the Associazione Davide e Gionata, the trans association Crisalide AzioneTrans and the women's publishing house Il dito e la luna, which provided a closed caravan into which Pride-goers could retire for a quiet read. However the lasting consequences of the year-long cycle of Pride events are more difficult to gauge. Claudia was convinced that 'more visibility means more freedom', but given the complex nature of visibility itself, the reactions it may provoke, the anxieties it may produce and the compromises it may demand, this view seems a little too idealistic.

Recent sociological work on the LGBT population in Turin seeks to raise its profile by emphasising the commonalities between homosexual and heterosexual people - for example, the significantly titled Diversi $d a$ chi? opens with an assertion that all people are complex, whatever their sexual orientation (Saraceno 2003, 11). Yet is it helpful to claim 'equality' in this way while LGBT individuals are not equal before the law? Fabio Bozzato of Arcigay Dedalo, Venice, argues that seeking visibility as 'normal' individuals is not necessarily a productive strategy for LGBT communities: 'It is not by presenting ourselves as the most normal and well-behaved people, as the most understated people possible that we will win our rights' (cited in Trappolin 2005, 278). Here he echoes 
Halberstam's $(2005,228)$ critique of 'normal gays' as 'cleaving to the ordinary and the quiet', and Shepard's characterisation of the American homophile movement as 'apologist'. Such remarks further recall Fuss's observations about the impossibility of coming 'out' and staying 'out': to be accepted as 'culturally intelligible' to mainstream society is implicitly to compromise on diversity. The tensions between legal equality and respect for difference, between wanting 'Equal rights for all' ('Uguali diritti per tutti') and asserting that 'No two of us are alike' ('Nessuno uguale'), complicate the struggle to improve social and political visibility in productive ways for LGBT individuals. In an American context, Andrew Sullivan argues that while there has been a significant increase in the number of publicly visible LGBT people, 'homosexuals are still systematically discriminated against by the state' (cited in Seidman 2002, 3; emphasis in original) - a situation that is echoed by developments in Italy: the visible presence of gay deputies such as Nichi Vendola is clearly positive, but the DICO legislation is a poor substitute for the demands made during the PACS campaign, not to mention the myriad other ways in which LGBT individuals are disadvantaged due to the lack of clear antidiscrimination laws (Pietrantoni 2006, 5).

The impressive efforts of the Pride committee and the LGBT (and non-LGBT) communities who participated in the programme in Turin are to be commended, and it is to be hoped that 'old orders' have indeed been shaken up, as Franco envisaged. However, homophobia is often deeply ingrained in social norms and behaviours, and requires more than a poster campaign or increased visibility of a segment of the population for it to abate. This was all too tragically demonstrated one year on from National Pride in the case of a young boy who committed suicide after homophobic bullying at his school in Turin (Schiavazzi 2007). In order for visibility to really mean 'full acceptance of self' as Cucco understands it, there must be a significant shift in opinion and perspective on the part of the mainstream population so that being recognised as 'normal' does not require a flattening, invisibilisation and normalisation of the rich and diverse characteristics of LGBT living and loving.

\section{Acknowledgements}

I would like to thank Chiara Bertone, Enza Minutella and all those in Turin whose generosity and openness made this research possible. Thanks also to the anonymous reviewers for their helpful comments.

\section{Notes}

1. Interview conducted by the author, 31 March 2006.

2. In contrast, civil partnerships in the United Kingdom are exclusively for same-sex couples.

3. Prodi wrote to Francesca Polo and Sergio Lo Giudice, presidents of Arcilesbica and Arcigay respectively, on 1 March 2006, declaring his solidarity with their cause (Arcigay 2006).

4. Arcigay was founded in 1985; Arcigaydonna (1989) and finally Arcilesbica (1994) followed (see http://www.arcigay.it). They are branches of the Arci network: Associazione ricreativa culturale italiana (Italian Cultural and Recreational Association) (see http:// www.arci.it).

5. The participation of this man, Franco, was coincindental rather than planned, but his perspective certainly added a productive dimension to interviewee responses. With the exception of the members of the organising committee, the names of interviewees have been changed to protect anonymity. 
6. For more information on the Sandro Penna Foundation, see their website: http:// www.arpnet.it/fsp

7. The name is inspired by the radio programme 'L'Altro martedi', which focuses on issues of homosexuality (Dall'Ovo 2007). The subversive wordplay at work makes the name of the group difficult to translate. Martedi (Tuesday) has been rendered feminine, to reflect the group's all-female nature. The name suggests an alternative mode of socialisation, but also an alternative mode of linguistic communication that frees the Italian language from the patterns of gendering that tend to invisibilise women and the feminine. This might be considered an example of 'écriture feminine' as identified by French feminists such as Luce Irigaray and Julia Kristeva.

8. For more information on the remit and organistion of the Circolo Maurice, see their website: http://www.mauriceglbt.org/html/

9. The fear of being the only lesbian in the world is an issue that has been satirised by lesbian groups (see the cartoon in Santini and Santini (2001, 78-9)), but is also taken seriously as isolation can lead to fatal consequences.

10. Being on the LGBT 'scene' is understood as participating actively in the social, cultural and political life of the community in some way; non-scene individuals are those who choose not to ally themselves with this community. Being non-scene is not the same as being 'closeted'.

11. Of course, many lesbians deliberately seek to be 'misrecognised' as male (see Halberstam (1998, $234,246-7)$ on butch women who sometimes rely on passing as male and 'butch realness'). However, that was not the case in this instance.

12. Susan Krieger, cited in Rothenberg $(1995,171)$.

13. Rothenberg (1995) refers to Benedict Anderson's work on 'imagined communities'.

14. See the observations made by Franco Grillini, former President of Arcigay (Sabelli Fioretti 2007, 15-6).

15. See the website for more information: http://www.turinglfilmfestival.com/2007/index.htm

16. See the website for more information: http://digilander.libero.it/freespirit1281/mai/ gaya2004.html

17. On the website for National Pride 2007, held in Rome (http://www.romapride.it/), the event is referred to as both 'Pride' and 'Gay Pride', but the main logo reads 'Rome Pride 2007: equality, dignity, secularity' (Roma Pride 2007: parità, dignità, laicità). See also Grillini’s comments in Sabelli Fioretti $(2007,37-8)$.

18. Held 26 January 2006 at the Museo Diffuso della Resistenza.

19. The London Gay Men's Chorus performed in Settembre musica at the Auditorium Giovanni Agnelli Lingotto on 12 September 2006; two recent publications were discussed in particular at the Fiera del libro (4-8 May): Giartosio and Goretti (2006) and Cecchi Paone (2006).

20. I am not able in this context to discuss in detail all of the many events organised for Pride (http://www.torinopride2006.it/). Please see the Pride calendar of events website for more information: http://www.torinopride2006.it/new/en/calendario.htm

21. Two forms of the acronym LGBT are in current usage: LGBT and GLBT. I have chosen to privilege the former since the order of the letters can be seen to reflect the dominant sociocultural visibility of gay men over lesbians, which is partially symbolically undone by placing the category 'lesbian' before 'gay'. Extended or abridged acronyms are also used depending on the constituency indicated - e.g., LGT, GLBTQ (in which 'Q' stands for 'queer'). Interviewees in Turin predominantly used the form 'GLBT'.

22. See the Gay Shame website for more information: http://www.gayshamesf.org/

23. This is reminiscent of the first Stonewall protest in Philadelphia in 1969, when men and women paraded silently, holding banners but dressed soberly in suits and skirts so as to demonstrate their proximity to 'normal' professional citizens. The conference 'Il soggetto lesbica: sovvertire il pensiero egemone per una ri-scrittura del simbolico' was held at the Centro Separatista Femminista, Casa Internazionale delle Donne.

24. For a rich discussion of the 'pros and cons' of PACS, as legislation that valorises same sex relationships but has been criticised for encouraging LGBT people to emulate heterosexual couples and for ignoring the needs of single or non-monogamous LGBT individuals, see Towanda 18, June-August 2005. 
25. Notably, although Sergio Chiamparino did lend his support to this leaflet, he did not attend the parade, reportedly because he 'would feel uncomfortable attending that kind of demonstration' (Casagrande 2006). Mercedes Bresso was very visibly present.

\section{References}

Agedo (Settore Pari Opportunità e Politiche di Genere Divisione Servizi Educativi with Associazione Genitori di Omosessuali). 2005. Nessuno uguale. Agedo: Milan.

Anon. 2006a. Cattolici italiani favorevoli ai Pacs e anche a divorzio e aborto. La Repubblica, 17 January. Available online at: http://www.repubblica.it/2006/a/sezioni/cronaca/pacs/pacs/ pacs.html.

Anon. 2006b. Ruini: 'Attenti alla famiglia, no ai Pacs'. La Repubblica, 20 March. Available online at: http://www.repubblica.it/2006c/sezioni/politica/versoelezioni40/parlaruini/parlaruini.html

Altman, D. 1974. Homosexual oppression and liberation. London: Allen Lane.

Arcigay. 2006. Prodi scrive ad Arcigay ed ArciLesbica. Comunicato stampa Arcigay Arcilesbica, 8 March. Available online at: http://www.arcigay.it/show.php?1830

Barbagli, M. and A. Colombo, eds. 2001. Omosessuali moderni: Gay e lesbiche in Italia. Bologna: Il Mulino.

Bonerandi, E. 2005. Milano, in centomila al Gay Pride 'Sì alla legge sui Pacs o non votiamo'. La Repubblica, 5 June. Available online at: http://www.arcigaymilano.org/dosart.asp?ID=22363.

Butler, J. 1991. Imitation and gender insubordination. In Inside/out: Lesbian theories, gay theories, ed. D. Fuss, New York/London: Routledge.

Butler, J. 2004. Undoing gender. London: Routledge.

Casagrande, O. 2006. I Pacs irrompono nel Gay pride. Il Manifesto, 17 June, p. 9.

Carter, D. 2004. Stonewall: The riots that sparked the gay revolution. New York: St Martin's Press.

Cecchi Paone, A. 2006. A viso aperto: Dopo il coming out: lettere da un continente sommerso. Venice: Marsilio.

Cristallo, M. 1996. Uscir fuori: Dieci anni di lotte omosessuali in Italia, 1971-1981. Milan: Teti.

Dall'Ovo, E. 2007. L'Altro Martedì e Radio Popolare: da 26 anni una coppia di fatto!. In We will survive: Lesbiche, gay e trans in Italia, ed. Paolo Pedote and Nicoletta Poidimani, Milan: Mimesis Edizioni.

Davis, T. 1995. The diversity of queer politics and the redefinition of sexual identity and community in urban spaces. In Mapping desire: Geographies of sexualities, ed. D. Bell and G. Valentine, London: Routledge.

Faderman, L. 1991. Odd girls and twilight lovers: A history of lesbian life in twentieth-century America. New York: Columbia University Press.

Firestein, B.A. 1996. Bisexuality: The psychology and politics of an invisible minority. London: Sage. Fuss, D., ed. 1991. Inside/out: Lesbian theories, gay theories. New York/London: Routledge.

Giartosio, T. 2004. Perché non possiamo non dirci: letteratura, omosessualità e mondo. Milan: Feltrinelli.

Giartosio, T. and G. Goretti. 2006. La città e l'isola: Omosessuali al confino nell'Italia fascista. Rome: Donzelli.

Goffman, E. 1963. Stigma: Notes on the management of spoiled identity. Englewood Cliffs, NJ: Prentice Hall.

Halberstam, J. 1998. Female masculinity. London: Duke University Press.

Halberstam, J. 2005. Shame and white gay masculinity. Social Text 23, no. 3-4: 84-5, 219-34.

Maher, M. and W. Pusch. 1995. Speaking 'out': The implications of negotiating lesbian identity. In Beyond the lavender lexicon: Authenticity, imagination and appropriation in lesbian and gay languages, ed. W.I. Leap, Amsterdam: Gordon \& Breach.

Minucci, E. 2006. Tutti contro il grande assente. La Stampa, 18 June, p. 40. 
Namaste, V.K. 2000. Invisible lives: The erasure of transsexual and transgendered people. Chicago, IL: University of Chicago Press.

Pietrantoni, L. 2006. Saperi innominabili: la ricerca psicosociale sugli orientamenti sessuali in Italia. In Omosapiens: Studi e ricerche sugli orientamenti sessuali, ed. D. Rizzo, Rome: Carocci.

Rossi Barilli, G. 1999. Il movimento gay in Italia. Milan: Feltrinelli.

Rothenberg, T. 1995. 'And she told two friends': Lesbians creating urban social space. In Mapping desire: Geographies of sexualities, ed. D. Bell and G. Valentine, London: Routledge.

Sabelli Fioretti, C. 2007. Gay: Molti modo per dire ti amo. Claudio Sabelli Fioretti intervista Franco Grillini. Reggio Emilia: Aliberti Editore.

Santini, S. and V. Santini. 2001. Diario di una misogina che ama le donne. Rome: CLI Azione Gay e lesbica.

Santucci, G. 2006. Gay Pride, la Pollastrini sfila. Il Corriere della Sera, 18 June, p. 10.

Saraceno, C., ed. 2003. Diversi da chi? Gay, lesbiche, transsessuali in un'area metropolitana. Milan: Guerini e associati.

Schiavazzi, V. 2007. Tormentato a scuola: 'Sei gay', 'Si uccide'. Il Corriere della Sera, 5 April. Available online at: http://www.corriere.it/Primo_Piano/Cronache/2007/04_Aprile/05/ scuola_suicida_gay.shtml

Seidman, S. 2002. Beyond the closet: The transformation of gay and lesbian life. New York/London: Routledge.

Shepard, B. 2001. The queer/gay assimilationist split: The suits vs. the sluts. Monthly Review 53(1). Available online at: http://www.monthlyreview.org/0501shepard.htm

Smargiassi, M. 2005. Tsunami, la parola dell'anno; solo i pacs insidiano il primato. La Repubblica, 23 December. Available online at: http://www.repubblica.it/2005/1/sezioni/spettacoli_e_cultura/parolanno/parolanno/parolanno.html

Trappolin, L. 2005. Gay is good: Riconoscimento della differenza omosessuale e definizione del'omosessualità. In Donne e uomini e cambiano: Relazioni di genere, identità sessuali e mutamento sociale, ed. E. Ruspini, Milan: Guerini e associate.

Valocchi, S. 2005. Not yet queer enough: The lessons of queer theory for the sociology of gender and sexuality. Gender and Society 19: 750-70.

Weeks, J. 1985. Sexuality and its discontents. London: Routledge. 